Volume I Tahun 2021

November 2021
E-ISSN: 2808-5361

http://e-journal.fkmumj.ac.id/
Proceeding The First

Muhammadiyah InternasionalPublic Health and Medicine

Conference

\title{
Literature Review: Causes of Stunting in Toddlers
}

\author{
Ghina Mutiara Tasyrifah \\ Master of Public Health, Faculty of Public Health, Muhammadiyah University of Jakarta \\ KH Ahmad Dahlan St, Cireundeu, Kec. Ciputat, South Jakarta, 15419 \\ Email: ghinamt17@gmail.com
}

\begin{abstract}
Stunting is a condition in which chronic malnutrition is caused by inadequate nutritional intake for a long period due to feeding that is not by nutritional needs. This article aims to review the factors that cause stunting, including maternal knowledge and parenting patterns, nutritional intake, low birth weight (LBW), and family economic status. A literature review was conducted by searching relevant articles from the electronic database (Google Scholar) using the following keywords: "causes of stunting" and "factors of stunting" in Indonesian and English. Ten articles were selected based on the following inclusion criteria: publication date from 2015 to 2021, discussing the causes of stunting that occurs in children's golden age, Indonesian language articles, full text, open access, and academic journals. Articles were analyzed using a matrix table. Factors causing stunting at the golden age of children are caused by lack of knowledge of mothers and parenting patterns, nutritional intake, low birth weight, and economic status. Stunting is very vulnerable to occur at the golden age of children due to the factors already mentioned previously. Recommended programs to increase parental knowledge such as antenatal care, maternal nutrition during pregnancy, monitoring of child nutrition, and information on parenting. Stunting is very vulnerable to occur at the golden age of children due to the factors already mentioned previously. Recommended programs to increase parental knowledge such as antenatal care, maternal nutrition during pregnancy, monitoring of child nutrition, and information on parenting. Stunting is very vulnerable to occur at the golden age of children due to the factors already mentioned previously. Recommended programs to increase parental knowledge such as antenatal care, maternal nutrition during pregnancy, monitoring of child nutrition, and information on parenting.
\end{abstract}

Keywords: Stunting, LBW, Nutritional intake, Parenting. 
E-ISSN: 2808-5361

http://e-journal.fkmumj.ac.id/
Proceeding The First

Muhammadiyah Internasional-

Public Health and Medicine

Conference

\section{INTRODUCTION}

Stunting is a condition in which chronic malnutrition is caused by inadequate nutritional intake for a long period due to feeding that is not by nutritional needs (Novianti, Mardianti, and Muchtar, 2020). According to the World Health Organization (WHO), stunting in children under five is a public health problem if the prevalence reaches 20\%. Based on the Nutrition Status Monitoring (PSG) (2017), the prevalence of stunting under five in Indonesia is 29.6\% (Lestari and Dwihestie, 2010).

One of the indirect causes of the stunting problem is the socioeconomic level, the family's ability to meet the nutritional needs of toddlers, besides that socioeconomic conditions also affect the choice of additional food types and timing of feeding and healthy living habits (Ngaisyah, 2015). One of the risk factors that influence the incidence of stunting in children under five is a history of low birth weight (LBW). As a result, the growth of LBW babies will be disrupted, if this situation continues with inadequate feeding, frequent infections, and poor health care can cause stunting in children. However, the incidence of stunting is indirectly influenced by socio-economic factors, such as education level, income, and the number of household members (Alba, Suntara, and Siska, 2021).

If stunting is not handled properly, it can have negative impacts, including physically experiencing delays or becoming short toddlers which can hinder achievement in terms of sports and other physical abilities, besides that stunting can cause problems in the cognitive aspects of children's intellectual abilities below standard. unlike other children whose growth is in the normal category (Noorhasanah \& Tauhidah, 2021). This article aims to analyze the literature on the causes of stunting from aspects of maternal knowledge, parenting patterns, nutritional status and low birth weight, and family economic status.

\section{METHODS}

This literature review was carried out in stages: determining PICO questions (Problem, Intervention, Comparison, Outcome), article search, assessment of relevant articles, and article analysis and synthesis. Relevant articles are searched through the electronic database, namely Google Scholar, using the keywords "causes of stunting" and "factors of stunting" in Indonesian. Ten articles were selected based on inclusion criteria: publication date for the last 6 years from 2015 to 2021, discussing the factors that cause stunting in children, in Indonesian, full text, open access, and an academic journal. Content analysis was carried out using a matrix table by comparing research methods, research subjects, and places, and the variables studied included mother's knowledge, parenting, 


\section{RESULTS AND DISCUSSION}

Table 1. Results of the Synthesis of Articles

\begin{tabular}{|c|c|c|c|c|}
\hline NO & CITATION & METHOD & SAMPLE/PLACE & RESULTS \\
\hline \multirow[t]{2}{*}{1} & Lestari and & This study uses a & Sample: 70 toddlers & There is a relationship between \\
\hline & Dwihestie (2020) & $\begin{array}{l}\text { quantitative } \\
\text { correlation } \\
\text { research method } \\
\text { with a case- } \\
\text { control time } \\
\text { approach which } \\
\text { is traced } \\
\text { retrospectively. }\end{array}$ & $\begin{array}{l}\text { Location: Sumberarum } \\
\text { and Sumbersari villages, } \\
\text { working area of } \\
\text { Moyudan Health Center, } \\
\text { Sleman Yogyakarta }\end{array}$ & $\begin{array}{l}\text { exclusive breastfeeding and the } \\
\text { incidence of stunting in the } \\
\text { Moyudan Sleman Public Health } \\
\text { Center Yogyakarta with a p- } \\
\text { value < } 0,000 \text {. The result of } \\
\text { simple correlation analysis (r) } \\
\text { shows the correlation between } \\
\text { exclusive breastfeeding and } \\
\text { stunting (r) is } 0.429 \text {. This shows } \\
\text { that there is a fairly strong } \\
\text { relationship between exclusive } \\
\text { breastfeeding and the incidence } \\
\text { of stunting. } \alpha\end{array}$ \\
\hline
\end{tabular}

\begin{tabular}{|c|c|c|c|c|}
\hline 2 & $\begin{array}{l}\text { Asikin, Ismail and } \\
\text { Utiya (2019) }\end{array}$ & $\begin{array}{l}\text { Using a cross- } \\
\text { sectional } \\
\text { research design } \\
\text { was used to } \\
\text { determine the } \\
\text { relationship } \\
\text { between the } \\
\text { independent } \\
\text { variable and the } \\
\text { dependent } \\
\text { variable. }\end{array}$ & $\begin{array}{l}\text { Sample: } 30 \text { stunting } \\
\text { toddlers and respondents } \\
\text { are mothers of toddlers } \\
\text { Place: Tabumela Village }\end{array}$ & $\begin{array}{l}\text { The results of the study showed } \\
\text { that the chi-square test results } \\
\text { obtained P-value for the LBW } \\
\text { factor, namely } 0.009 \text {, and for the } \\
\text { nutritional parenting factor, } \\
\text { namely } 0.000 \text {, which means less } \\
\text { than }=0.05 \text {. This research is } \\
\text { expected to be useful as a source } \\
\text { to prevent stunting, the better the } \\
\text { mother's parenting and the lower } \\
\text { the incidence of LBW in infants, } \\
\text { the lower the incidence of } \\
\text { stunting. } \alpha\end{array}$ \\
\hline 3 & $\begin{array}{l}\text { Murti, Suryati and } \\
\text { Oktavianto }(2020)\end{array}$ & $\begin{array}{l}\text { The research } \\
\text { design used a } \\
\text { case-control with } \\
\text { design a } \\
\text { correlational } \\
\text { analytic methods } \\
\text { and } \\
\text { retrospective } \\
\text { approach. sample } \\
\text { of } 32 \text { cases and } \\
32 \text { controls with } \\
\text { purposive } \\
\text { sampling } \\
\text { technique, data } \\
\text { analysis using } \\
\text { chi-square. }\end{array}$ & $\begin{array}{l}\text { Sample: toddlers aged 2- } \\
5 \text { years } \\
\text { Place: } \quad \text { Umbulrejo } \\
\text { Village, } \quad \text { Ponjong, } \\
\text { Gunungkidul. }\end{array}$ & $\begin{array}{l}\text { The results of the study obtained } \\
\text { that } 27(42.2 \%) \text { toddlers had a } \\
\text { history of low birth weight and } \\
32 \quad(100 \%) \text { toddlers who } \\
\text { experienced stunting. The results } \\
\text { of the Chi-Square test show a p- } \\
\text { value }<0.000 \text { and an OR value } \\
\text { of } 0.056 \text {. } \\
\text { Thus, there is a significant } \\
\text { relationship between LBW and } \\
\text { the incidence of stunting in } \\
\text { toddlers aged } 2-5 \text { years in } \\
\text { Umbulrejo Village }\end{array}$ \\
\hline 4 & Mawaddah (2019) & $\begin{array}{l}\text { Observational } \\
\text { analytic research } \\
\text { method with } \\
\text { retrospective }\end{array}$ & $\begin{array}{l}\text { Sample: } 78 \text { toddlers } \\
\text { 24-36 months old } \\
\text { Location: } \quad \text { Tampans }\end{array}$ & $\begin{array}{l}\text { The statistical test results } \\
\text { showed } p<0.000 \text { and the OR } \\
\text { value was } 29.558 \text {. There is a } \\
\text { significant relationship between }\end{array}$ \\
\hline
\end{tabular}




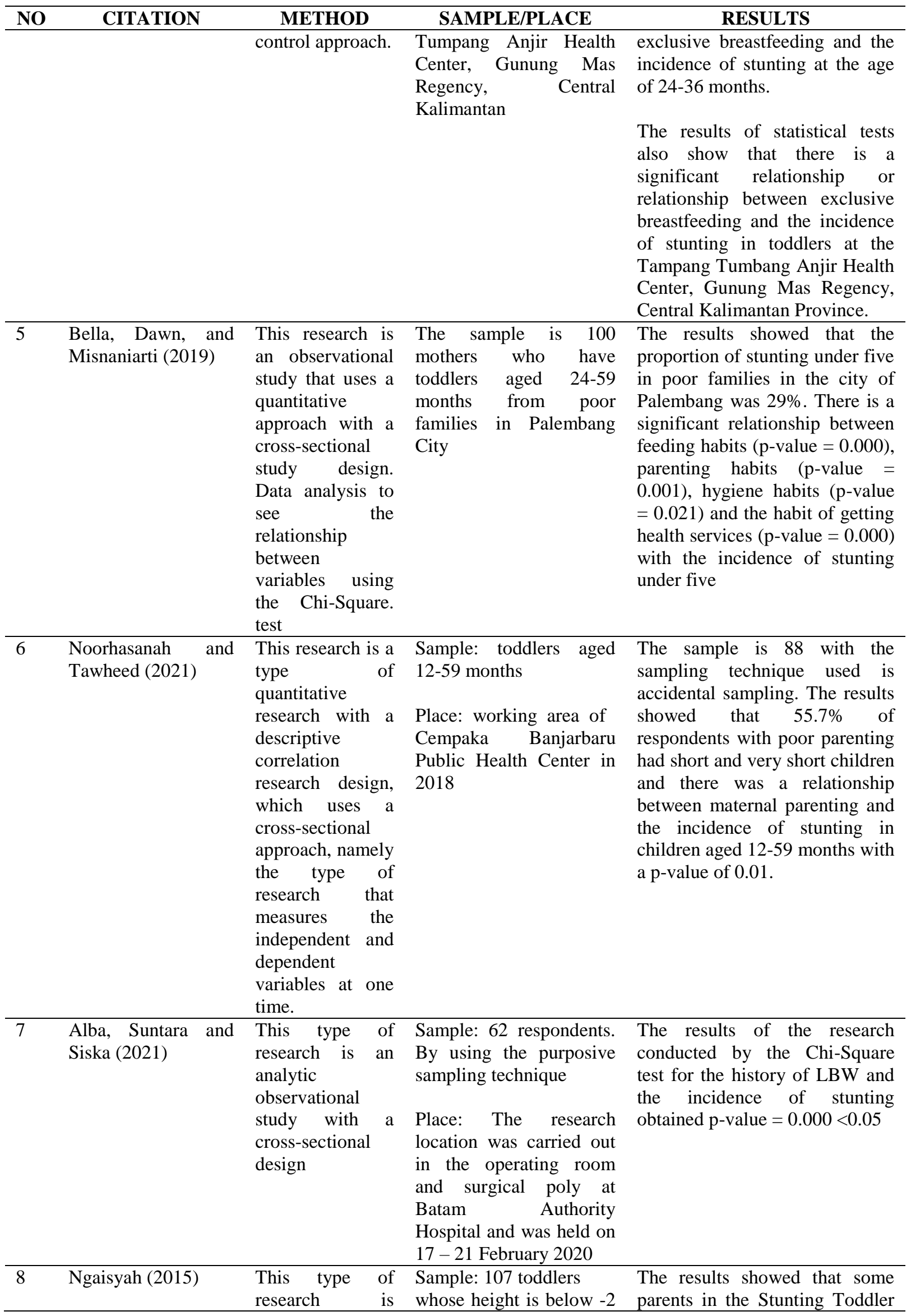




\begin{tabular}{|c|c|c|c|c|}
\hline NO & CITATION & METHOD & SAMPLE/PLACE & RESULTS \\
\hline & & $\begin{array}{l}\text { observational in } \\
\text { the field of } \\
\text { community } \\
\text { nutrition with a } \\
\text { cross-sectional } \\
\text { design. }\end{array}$ & $\begin{array}{l}\text { Standard Deviation from } \\
\text { the median value } \\
\text { according to the } \mathrm{Z} \text { score } \\
\text { calculation based on the } \\
\text { TB/U or PB/U index } \\
\text { Place: in Kanigoro } \\
\text { village, Saptosari, } \\
\text { Gunung Kidul. }\end{array}$ & $\begin{array}{l}\text { group had basic education as } \\
\text { many as } 104 \text { respondents } \\
(92.86 \%) \text { most of them had } \\
\text { farmer jobs as many as } 75 \\
\text { respondents }(66.97 \%) \text { and most } \\
\text { of the income was below the } \\
\text { regional drinking wage (< } \\
\text { UMR). as many as } 67 \\
\text { respondents (59.82\%). The } \\
\text { results of the bivariate study } \\
\text { found that two variables } \\
\text { (Education, and Income) were } \\
\text { significantly related to the } \\
\text { incidence of stunting (p-value } \\
<0.05) \text {. }\end{array}$ \\
\hline 9 & $\begin{array}{l}\text { Novianti, Mardianti } \\
\text { and Muchtar (2020) }\end{array}$ & $\begin{array}{l}\text { This study used a } \\
\text { cross-sectional } \\
\text { design. }\end{array}$ & $\begin{array}{l}\text { Sample: } 105 \text { toddlers } \\
\text { aged 12-36 months } \\
\text { Place: Ulaweng Health } \\
\text { Center, Bone Regency }\end{array}$ & $\begin{array}{l}\text { There is a relationship between } \\
\text { exclusive breastfeeding and } \\
\text { stunting where the p-value is < } \\
0.05 \text { and there is a relationship } \\
\text { between LBW and stunting } \\
\text { where the p-value is }<0.05 \text {. }\end{array}$ \\
\hline 10 & $\begin{array}{l}\text { Raharja, Waryana } \\
\text { and Sitasari (2019) }\end{array}$ & $\begin{array}{l}\text { The type of } \\
\text { research } \\
\text { conducted is an } \\
\text { analytical survey } \\
\text { (observational) } \\
\text { with a case- } \\
\text { control study } \\
\text { approach. }\end{array}$ & $\begin{array}{l}\text { Sample: toddler aged } \\
\text { 24-59 months } \\
\text { Place: Bejiharjo Village }\end{array}$ & $\begin{array}{l}\text { Bivariate analysis showed that } \\
\text { the economic status of parents } \\
(\mathrm{p}=0.002 ; \text { OR }=3.182) \text { and } \\
\text { family food security }(\mathrm{p}=0.007 \text {; } \\
\text { OR=3.164) were risk factors for } \\
\text { stunting in children under five in } \\
\text { Bejiharjo Village. }\end{array}$ \\
\hline
\end{tabular}

Ten articles were analyzed using a matrix table (table 1) to see the variables studied by each study and their relationship to the incidence of stunting. Of the 10 articles, there are 6 articles with a cross-sectional study design, including using an analytical observational approach and using secondary data collected from surveys. Of the ten articles all in Indonesian, 4 articles took study locations in the city of Yogyakarta and others from the cities of Batam, Gorontalo, Bone, Banjarmasin, Palembang, and Central Kalimantan.

The focus of this literature review is the mother's knowledge, parenting style, low birth weight, nutritional status, and family economic status.

The results of the analysis are grouped into three categories and their relationship to the incidence of stunting, namely:

(1) knowledge of mothers and parenting styles,

(2) LBW and nutritional status, and

(3) family economic status.

Of the ten articles, 2 articles discuss the relationship between parenting patterns and stunting in children. In their research, Noorhasanah and Tauhidah (2021) found that children with very short stunting had poor or poor parenting (69.4\%). Meanwhile, the condition of children with short 
stunting, also found that parenting was not good or said to be bad around (30.6\%), from the statistical test results obtained a p-value of 0.01 which means that there is a relationship between maternal parenting and the incidence of stunting. so that it can be interpreted that if the parenting pattern is good, the stunting category is lower, as well as if the mother's parenting pattern is in a bad category, the stunting category will be high. In this study, it was also found that most of the mothers had elementary school education. The role of the family, especially a mother in nurturing and caring for children, can have an impact on the child's growth and development. Mother's parenting is a mother's behavior in caring for or taking care of her child. Mother's behavior includes a role in providing breast milk or providing complementary foods, teaching proper eating procedures, providing food with high nutritional value, the ability to control the number of portions of food that must be consumed, preparing hygienic food, correct eating patterns, so that nutritional intake can be achieved. well received by children. However, the important thing that must also be considered is that the diet must be varied so that it makes children happy and likes a variety of healthy and nutritious foods. the ability to control the number of portions of food that must be consumed, prepare hygienic food, eat the right pattern, so that nutritional intake can be well received by children. However, the important thing that must also be considered is that the diet must be varied so that it makes children happy and likes a variety of healthy and nutritious foods. the ability to control the number of portions of food that must be consumed, prepare hygienic food, eat the right pattern, so that nutritional intake can be well received by children. However, the important thing that must also be considered is that the diet must be varied so that it makes children happy and likes a variety of healthy and nutritious foods.

Meanwhile, Bella, Fajar, and Misnaniarti (2019) also conducted a study in which the majority of the respondents were mothers aged over 35 years, namely 56 respondents. Most mothers have low education below high school as many as 65 respondents and most are housewives who have more time at home (73\%). The results showed that of all respondents, mothers with poor parenting habits for their toddlers mostly had stunting toddlers, namely $64.7 \%$. Meanwhile, of all respondents, mothers with good parenting habits only had $21.7 \%$ stunting. Of the 30 respondents, 5 toddlers were born with a history of LBW with short stature (16.7\%), while toddlers who were born with a history of not LBW were 6 toddlers $(20 \%)$. Toddlers born with a history of LBW with a very short body condition are 17 toddlers (56.7\%), while toddlers born with a history of not LBW are 2 toddlers (6.6\%) Asikin, Ismail, and Utiya (2019).

Of the ten articles analyzed, 4 articles discuss Low Birth Weight (LBW).

Alba, Suntara, and Siska (2021) conducted a study in September on 62 respondents, from the results of the study obtained data on the Relationship of LBW History with Stunting Incidents in Toddlers in the Work Area of the Sekupang Health Center Batam City in 2019. Based on the results of research in the Sekupang Health Center Work Area in 2019 This shows that 62 children under five, mostly with 
LBW totaling 25 people (40.3\%), stunted toddlers amounting to 40 (64.5\%). Research conducted by Novianti, Mardianti, and Muchtar (2020) shows that there is a relationship between LBW and the incidence of stunting in children aged 6-24 months, which is a 5.6 times higher risk of stunting in children with a history of LBW compared to children born with low birth weight. normal weight.

A similar study was also conducted by Murti, Suryati, and Oktavianto (2020) which showed the results that most of those who experienced LBW and also stunted were 23 toddlers (71.9\%), and a small portion who had LBW but not stunting were 4 toddlers (12.5\%). While most of those who did not experience LBW but were stunted were 9 toddlers (28.1\%), and a small portion who did not experience LBW and were also not stunted were 28 toddlers (87.5\%).

Of the ten articles analyzed, 2 articles discuss the socioeconomic status of stunting. Ngaisyah (2015) conducted a statistical study that showed a significant relationship between a father's education and the incidence of stunting. This situation is in line with the theory that parents who have higher education will be more oriented towards preventive action, know more about health problems, and have better health status. In addition, this study also shows that in the stunting group, more income is below the minimum wage, namely as many as 67 respondents (35.8\%), while those who have income above the minimum wage are only 45 people (22\%). This suggests that an increase in income will increase the opportunity to buy food of better quality and quantity,

Raharja, Waryana, and Sitasari (2019) also conducted a similar study where it can be concluded that the economic status of parents is a risk factor for stunting in toddlers in the work area of Karangmojo II Health Center, Gunungkidul Regency. Toddlers with low parental economic status have a 3.182 times higher risk of experiencing stunting when compared to toddlers whose parents have high economic status.

\section{CONCLUSION AND SUGGESTIONS}

Many factors can cause stunting in children under five, including low maternal knowledge, inappropriate parenting patterns, nutritional deficiencies, low birth weight, and low family economic status. To be able to reduce stunting in children under five, shared responsibility is needed that involves all parties, namely parents, health workers, and the government. Mother's knowledge, parenting, and nutritional status are modifiable factors, while low birth weight is a preventable factor. Programs designed to increase parents' knowledge and prevent LBW such as antenatal care, maternal nutritional intake during pregnancy, child nutrition are highly recommended. In addition, improving parenting practices including processing and feeding practices, personal and environmental hygiene practices, as well as the use of health facilities is also recommended to be socialized to the community, especially families with toddlers. 


\section{BIBLIOGRAPHY}

Alba, A, D., Suntara, D, A., \& Siska, D. (2021). The Relationship between Bblr History and Stunting Incidents in Toddlers in the Work Area of the Sekupang Health Center, Batam City in 2019. Journal of Research Innovation. Vol.1 No.12 May 2021.

Asikin, Z, F., Ismail, S., \& Utiya, M. (2019). Relationship between LBW and Nutritional Parenting with Stunting Incidence in Tabumela Village, Gorontalo Regency. Honey Journal of Health. Vol 8, No 2 (2019), 66-76. ISSN 2301-5683 (print) DOI: 10.31314/mjk.8.2.66-76.2019

Bella, F, D., Fajar, N, A., \& Misnaniarti. (2019). The relationship between parenting patterns and the incidence of stunting in children under five from poor families in the city of Palembang. Indonesian Journal of Nutrition (The Indonesian Journal of Nutrition), 8 (1), 2019.

Lestari, E, F., \& Dwihestie, L, K. (2020). Exclusive Breastfeeding Related to Stunting Incidents in Toddlers. Permas Scientific Journal: Kendal STIKES Scientific Journal Volume 10 No 2, Pages 129 - 136, April 2020.

Mawaddah, S. (2019). Relationship of Exclusive Breastfeeding with Stunting Incidence in Toddlers Age 24-36 Months (Case Study at Tampang Tumbang Anjir Health Center, Gunung Mas Regency, Central Kalimantan Province).

Murti, F, C., Suryati., \& Oktavianto, E. (2020). The Relationship Of Low Birth Weight (Lbw) With Stunting Events In Tolls Aged 2-5 Years Old In Umbulrejo Village, Ponjong, Gunung Kidul. Scientific Journal of Nursing Health. Volume 16, No. 2, December 2020, p. 52-60. DOI: 10.26753/jikk.v16i2.419

Ngaisyah, R, D. (2015). Social Economic Relationship With Stunting Events In Tons Of Children In Kanigoro Village, Saptosari, Gunung Kidul. Respati Medical Journal. Vol X Number 4 October 2015

Noorhasanah, E., \& Tawhidah, N, I. (2021). Relationship between Mother's Parenting Patterns with Stunting Incidence in 12-59 Months Age Children. Journal of Pediatric Nursing, Vol 4 No 1, May 2021 DOI: http://dx.doi.org/10.26594/jika.4.1.2021. 37-42 e-ISSN 2621-296X

Novianti, I., Mardianti, D., \& Muchtar, A, S. (2020). Breast Milk And Lbw Relationship With Stunting Events In Toddlers Aged 12-36 Months. Journal Of Midwife Vol 6, No 3, July 2020: 329-334.

Raharja, U, M, P., Waryana., \& Sitasari, A. (2019). The economic status of parents and family food security as risk factors for stunting in children under five in Bejiharjo Village. Indonesian Nutrition Science, Vol. 03, No. 01, August 2019: 73-82. 